\title{
A TESTSÚLYCSÖKKENTÉS PSZICHOLÓGIAI LEHETŐSÉGEI AKTÍV TÜZOLTÓK KÖRÉBEN
}

\author{
Szerző \\ Sáfrány Judit \\ Eszterházy Károly Egyetem
}

Szerző e-mail címe: safrany12@gmail.com

\section{Lektorok:}

Hanák Zsuzsanna (PhD, Habil.)

Eszterházy Károly Egyetem

Bodnár Gabriella (PhD, Habil.)

Soproni Egyetem

...és további két anonim lektor

\begin{abstract}
Absztrakt
Jelen tanulmány célja az aktív állományú tűzoltók körében a túlsúly és az elhízás lehetséges rizikófaktorainak feltárása, a magyarázó elméletek bemutatása, valamint a tartós életmódváltozásra való felkészülést segítő pszichológiai módszerek felajánlása. Az intervenciós lehetőségek közül a pszichoedukáció, a relaxáció, a kognitív és viselkedésterápiás technikák, valamint az önsegítő módszerek alkalmazása javasolt.
\end{abstract}

Kulcsszavak: elhízás, tűzoltó, kognitív viselkedésterápia, önsegítő módszer, stresszkezelés

Diszciplina: pszichológia, tűzoltó egészségügy

\section{Abstract}

PSYCHOLOGICAL METHODS OF WEIGHT LOSS FOR CAREER FIREFIGHTERS

Recent study aimed to reveal the potencial risk factors of overweight and obesity, to present the interpretative concepts, and to offer the supportive psychological methods in the population of career firefighters, in order to reach the permanent changes in their lifestyle. Among the potencial interventions psychological education, relaxation, cognitive-behavioral therapies, and guided self-help strategies are preferred.

Keywords: obesity, firefighter, cognitive-behavioral therapy, guided self-help, stress management

Disciplines: psychology, fire service health care

Sáfrány Judit (2020): A testsúlycsökkentés pszichológiai lehetőségei aktív tűzoltók körében. Lélektan és hadviselés - interdiszciplináris folyóirat, II. évf. 2020/1. szám. 79-93. doi: 10.35404/LH.2020.1.79 
A 21. század egészségkárosító jelenségei között a túlsúly és az elhízás kiemelt helyet foglal el, és komoly kihívás elé állítja az érintetteket és a szakembereket egyaránt. Mind az egyénre, mind a társadalom egészére nézve jelentős megterhelést jelent, és az Egészségügyi Világszervezet (WHO) osztályozása szerint a tíz legsúlyosabb betegség között tartható számon (Hu, 2008). Állíthatjuk ezt annak ellenére, hogy számtalan felkínált lehetôséggel találkozhatunk akár a drogériák polcain, akár a különböző reklámok kínálatában nézünk szét. Rövid távú testsúlycsökkenés valóban - aránylag - könnyen elérhető, azonban az egészségvédelem szempontjából hosszú távú változás a kívánatos.

A veszélyeztetett populáció közül a tűzoltók körében jelen lévő súlyproblémák nemcsak az egészség szempontjából jelentenek rizikót, hanem komoly foglalkoztatási, egzisztenciális akadályt is jelenthet, ha az egészségügyi szűrés alkalmával igazolódik a határeseti vagy ezt jelentősen meghaladó súlytöbblet. Jelen tanulmány célja az aktív állományú tűzoltók körében a lehetséges rizikófaktorok feltárása, a magyarázó elméletek bemutatása, valamint a tartós életmódváltozásra való felkészülést segítő pszichológiai módszerek felajánlása.

\section{Bevezetés}

Magyarországon az „57/2009. (X.30.) IRM-ÖM-PTNM együttes rendelet egyes rendvédelmi szervek hivatásos állományú tagjai egészségi, pszichikai és fizikai alkalmasságáról, közalkalmazottai és köztisztviselői munkaköri egészségi alkalmasságáról, a szol- gálat-, illetve keresőképtelenség megállapításáról, valamint az egészségügyi alapellátásról" (Netjogtár, 2020) szabályozza a hivatásos állományú tűzoltókkal szemben támasztott alkalmassági követelményeket, a szűrések során alkalmazott kritériumokat. Ennek elsődleges célja, hogy tűzoltók az optimális alkalmasság és készenlét által biztonsággal tudjanak teljesíteni a beavatkozások során (Soteriades és tsai, 2011). Ez az elv általános a nyugati kultúrák tűzoltói számára, ahol társadalmilag általános jelenség az elhízás (Poston és tsai, 2011), ami veszélyezteti a rendelet által felvázolt követelményeknek való megfelelést. Komoly egészségügyi, pszichológiai és fizikai elvárásoknak szükséges megfelelnie egy aktív tűzoltónak annak érdekében, hogy hivatását tartósan gyakorolni tudja. A fizikai állóképesség, rugalmasság, a megfelelő izomzat, erő és energia mind hosszú távú elvárások a beavatkozó állománnyal szemben (International Association of Fire Fighters, 2008). Evidenciának tűnhet ez alapján, hogy mindezek betartása természetesen megvalósul, és valamennyi tűzoltó problémamentesen készül a soron következő egészségügyi, pszichológiai, fizikai megpróbáltatásra. A társadalmi sztereotípiák szerint is egy tűzoltónak egészségesnek és fittnek kell lennie, mivel hivatása gyakorlása során számtalan erófeszítést kell tennie mind a tûzoltási, mind egy mentési múvelet közben. Azok a társadalomban is tapasztalható egészségügyi-pszichológiai megpróbáltatások, rizikótényezôk, amik a morbiditási és mortalitási mutatók tekintetében figyelemfelkeltőek, a tüzoltó populációban is jelen vannak. A legutóbbi, 2014-es felmérés szerint Magyarország felnőtt lakosságára vonatkozó- 
an a férfiak 28,2 \%- a, a nők 31,5\%-a közvetlenül érintett az elhízás kapcsán (Erdei és tsai, 2017).

Az alapellátásban résztvevő orvos és pszichológus azonban nemcsak az alkalmassági visszajelzésben lát el feladatot, hanem a prevenciós és intervenciós tevékenység is szerves részét képezi a munkának. Ez az interdiszciplináris megközelítés a gyakori testsúlyproblémák kapcsán kifejezetten szükséges lehet, hiszen a túlsúly és elhízás komoly egészségkárosító és pszichológiai szövődményt is magában rejt, és a megoldás is mindkét tudomány bevonásával valósulhat meg. A modern egészségfejlesztés szempontjából helytálló lehet a megfogalmazás ebben a problémakörben, mely szerint az orvos tudja, hogy mit, a pszichológus pedig, hogy hogyan.

Mivel egy ma szolgálatot teljesítő tűzoltónak hosszú távon szükséges helyt állnia a nyugdijas évek eléréséig, elengedhetetlen a megfelelő gondoskodás egészségi, pszichológiai és fizikai állapotuk optimális megőrzésével összefüggésben. Az egészségrizikó szempontjából a többletsúly azért érdemel kiemelt figyelmet, mert számos következményes ártalommal járhat, ami további alkalmatlansági rizikót jelenthet. Az élethossz 5-10 évvel megrövidülhet, amennyiben kezeletlen marad a probléma, valamint csökken azoknak az éveknek a száma, amit az egyén egészséges státuszban eltölthet (Pados és tsai, 2017). Szomatikus szempontból a magas vérnyomás, a diszlipidémia, a II-es típusú diabétesz, kardiovaszkuláris betegségek, osteoarthritis, alvási apnoé, daganatos elváltozások, légzőszervi problémák (például asztma) léphetnek fel (Pi-Sunyer, 2002; Sidó, 2003). A metabo- likus szindróma kockázatát párhuzamosan több, szintén az elhízással összefüggésbe hozható anyagcserezavar (többek között inzulinrezisztencia, magasabb trigliceridszint, diszlipidémia, hipertónia) növelheti, ami további veszélyt jelenthet a kardiológiai irányú megbetegedések kapcsán is (Hu, 2008). Az elhízás kóroki szerepének felismerése hoszszabb ideig a kardiovaszkuláris szövődmények területén volt uralkodó, napjainkban azonban a gasztrointesztinális kórképekkel is ismert a kapcsolat. A gastrooesophagealis reflux, a máj elzsírosodása és az epekő is ide sorolható problémaegyüttes (Gyökeres, Király, Lakatos és Madácsy, 2006). A krónikus morbiditási tények mellett a megnövekedett mortalitási aránnyal is számolnunk kell (National Institute of Health, 1998; World Health Organization, 2000; McGee, 2005; Flegal és tsai, 2013). Az Amerikai Egyesült Államokban szolgálatot teljesítő tűzoltók között nagy gyakorisággal fordul elő az elhízás (Gu és tsai, 2014), és ezzel párhuzamosan a szolgálatteljesítés közben bekövetkező kardiovaszkuláris elhalálozás magas rizikója (Kales és tsai, 2007; Geibe és tsai, 2008).

További felismerés, hogy a munkavégzéssel összefüggő sérülések szempontjából is magasabb kockázattal jár a többletsúly (Poplin és tsai, 2014). A tűzoltók alapvetően veszélyes szituációknak vannak kitéve a munkavégzés során, és a leggyakrabban húzódások és rándulások okoznak nehézséget a beavatkozás végeztével, ami főként a gyakori emelési manőverekből ered (Poplin és tsai, 2012). Jahnke és munkatársai (2013) eredményei alapján a mozgásszervi balesetek előrejelzésére is figyelembe kell venni a testtömeg-index és haskörfogat által meghatározott elhízást. 
Tehát munkavédelmi szempontból is jelentőséggel bír a megelőzés és a megfelelő kezelés a testsúlykontroll-probléma fellépésénél. Mindez azért is fontos, mert előzetes egészségügyi kockázat nélkül is ficamok, felületi sérülések, nyilt sebek, agyrázkódás, belszervi sérülések, csonttörések, illetve tûz vagy kemikália általi égési sérülések előfordulásáról számoltak be a vizsgálatban résztvevő tűzoltók.

Az átlagpopulációban az elhízás és a pszichés zavarok kapcsolata is bizonyítékon alapul, hiszen a depresszióval (de Wit és tsai, 2010) és a szorongással (Gariepy, Nitka és Schmitz, 2010) gyakori együttjárást mutat.

Az elhízás tehát általánosságban gondot okoz a tűzoltók számára, és az idő előrehaladtával romló tendencia azonosítható. Nemcsak a szakember saját egészsége és jólléte forog kockán, hanem a beavatkozások hatékonyságának csökkenésével a tágabb közösség biztonsága is veszélyeztetett (Moore, 2003). Ennek oka az elhízott tűzoltók alacsonyabb terhelhetősége, és nagyobb valószínűséggel tapasztalnak kedvezőtlen következményeket a magasabb hőhatás során, beleértve a napszúrást, kiszáradást (Chung és Pin, 1996; Donoghue és Bates, 2000).

\section{Rizikófaktorok a túlsúly kialakulásában}

A tűzoltó populáció szempontjából a hagyományos rizikófaktorok mellett egyéb kockázati tényezőket is figyelembe kell venni. Multifaktoriális megközelítés szükséges az elhízás etiológiáját tekintve, hiszen jelentős környezeti okok játszanak szerepet, úgymint a fizikai és pszichoszociális munkafeltételek, a kultúra és a szocioökonómiai státusz (Da- vidson és Knafl, 2006; Choi és tsai, 2011; Agne és tsai, 2012; Pandalai és tsai, 2013). Choi és munkatársai (2016) vizsgálata szerint a hivatásos férfi tűzoltók körében rizikót jelent az elhízásra a szokásos munkarendhez képest több 24 órás műszak vállalása (minimum 17x24 órás túlóra az elmúlt hónapban), valamint a hosszú ideig tartó ülőmunka. Ezek a faktorok függetlenül érvényesek egyéb munkafeltételektől, a szociodemográfiai változóktól, az egészségmagatartástól, valamint a pszichológiai distressztől.

Figyelemreméltó az a 2013-ban végzett kvalitatív vizsgálat, ami tipikusan a tűzoltók munkahelyi életformájára helyezte a hangsúlyt az elhízásban szerepet játszó lehetséges okok feltárásánál (Dobson és tsai, 2013). Öt területet találtak: a tûzoltó laktanyák evési kultúrája, az éjszakai riasztások és az alvás megszakítása, a parancsnoki hozzáállás és a fizikai fittség összefüggése, az ülőmunka, valamint az életkor és a generációs hatások. A vizsgálatban résztvevő amerikai tűzoltók két típusú étkezési szokást jelöltek meg: a „,családias” valamint a „házon kívüli étkezés” megoldás. A beszámolók szerint a nagyobb (kettő vagy több rajjal rendelkező) laktanyákban a családi típusú ételkészítés az uralkodó. Ennek menetrendje szerint a szolgálai napokon rotációs rendszerben zajlik a főzés lebonyolítása, és minden szolgálatban lévő állománytag anyagilag is hozzájárul az alapanyagok beszerzéséhez. Ezzel szemben a kisebb létszámú laktanyákban, ahol egyszerre 3-4 személy teljesít szolgálatot, preferáltabb az alacsony költségű családi kifőzdéktől vagy gyorséttermekből való ételrendelés. Alapvetően a többség akaratának befolyása a mérvadó, annak tekintetében is, hogy mennyire az egészséges- 
ség szempontja játszik szerepet az étel kiválasztásánál. Az étel mennyiségének meghatározásánál a családias módszer tűnik problémásnak: a szükségesnél nagyobb adagok elkészítése és elfogyasztása jellemző. Az aktuális „szakács” mindig arra törekszik, nehogy alulbecsülje az elfogyasztásra szánt porciót, illetve az összegyűjtött összegnek eleget tegyen, tehát „illik” bőven teljesíteni a napi adagot. Így sajnos a mennyiség előnyt élvez a minőséggel szemben, hiszen diétás étel felszolgálása „kellemetlen” helyzetbe hozná az ételkészítőt. A tűzoltó laktanyákban a „férfias ételek" (vörös hús és gazdag szénhidtráttartalom, stb.) fogyasztása alapvető elvárás, hiszen az a hagyományos nézet uralkodik, hogy fel kell tölteni az energiaraktárakat annak érdekében, hogy a kilátásban lévő fizikailag megterhelő, tevékeny és forgalmas szolgálat igénybevételére felkészüljenek. Mivel azonban a vonulásszám csökkenése és az ülőmunka megnövekedett aránya (adminisztratív feladatok és az Egyesült Államokban a számítógépes szimulációs gyakorlatok térhódítása) mellett a táplálékbevitel nem csökkent, az többletsúly veszélye fokozott.

Egyéb vélemény szerint a fiatalabb tûzoltókkal szembeni elvárásként megfogalmazódott, hogy többet egyenek, kivívva ezzel a tapasztaltabb társaik tiszteletét. A gyakori riasztások félbeszakíthatják az étkezéseket, ami a túl gyors tempójú evési szokásokat, valamint a gyorsan elkészíthetô receptek preferenciáját rögzítette. Egy másik, evéshez köthető hagyomány az amerikai tűzoltók körében az első tapasztalatok bajtársias, jégkrémmel történő „megkoronázása” (például az első tűzeset után).
A magas kalóriájú nassolás szintén rizikót jelent a súlygyarapodásra, mivel könnyen elérhető, gyakran pótcselekvésként szolgál, illetve az éjjeli ébredések mindenütt jelenlévő „kelléke”. Emellett a szintén magas kalóriatartalmú energiaitalok gyakran előkerülnek az éberség szinten tartására. Történik ez sokszor a fáradtság mértékétől függetlenül (annak érdekében, hogy folyamatos készenlétben legyenek a riasztások esetére), és a koffeinfogyasztás túlzott mértéket ölt, ami az alvásminőségre is befolyással van. A tűzoltók alapvetően is megváltozott alvási ciklusról és mélységről számolnak be, ugyanis meglehetősen „éberalvók”.

A parancsnoki hozzáállás a fizikai fittséget azáltal képes befolyásolni, mennyiben facilitálja illetve engedélyezi a vezető a szolgálatban történő sporttevékenységet, ami az energiabevitel és - felhasználás egyensúlyának megteremtésében fontos szerepet játszik.

$\mathrm{Az}$ életkor és a generációs sajátosságok kapcsán nincs egyértelmű egyetértés. Egyes tapasztalatok szerint az idősebb korosztály esetében jellemző az alacsonyabb szintű egészségmagatartás és az elhízás. Ennek okai között a családon belüli és a munkahellyel összefüggésben megnövekedett felelősséget, a versengő hozzáállást és a jó fizikai állapotra fókuszálás ritkulását, illetve az ülőmunka magasabb arányát tartják számon. A fiatalabb, úgynevezett „Facebook-generáció” azonban más indíttatásból hajlamos a passzív tevékenységformákra, mivel az ő szocializációs folyamatukban a mobiltelefonok, a számítógépes játékok, illetve az internethasználat aránytalan szerepet kapott. Az amerikai vizsgálati mintán végzett megfigyelések ugyan korlátozottan érvényesek a magyarországi 
tűzoltó populációra, mégis több szempontból párhuzamot találhatunk és a prevenciósintervenciós feladatok számára támpontot jelenthetnek - mind az egyéni, mind a közösségi szinten.

\section{Lehetséges magyarázatok}

\section{az elégtelen testsúlykontroll kapcsán}

A tapasztalatok szerint egy probléma természetének megértése, a lehetséges akadályozó, illetve szupportív tényezők feltárása önmagában motivációébresztő és teljesebb kontroll megélését teszi lehetôvé egy feladat megoldása során. Ezért minden intervenciós támogatás megkezdése előtt a probléma természetének hátterét érdemes megvizsgálni.

Az evési magatartás az elmúlt évszázadokban jelentôs változáson ment keresztül. Korábban csak a felsőbb társadalmi rétegek , kiváltsága" volt az elhízás, majd a szerényebb színvonalon élők számára is gyakorlatilag korlátlan mennyiségű étel állt rendelkezésre. És ezzel elindult az evolúciós tapasztalatok maladaptív térhódítása. A természetben élő állatok rendelkeznek azzal a veleszületett képességgel, hogy ösztönösen kontrollálni tudják, mit, mikor és mekkora mennyiségben esznek, így nem fenyegeti őket az elhízás veszélye (ez a folyamat azonban fogságba kerülve zavart szenved - Forgács, 2008). Napjainkban az ételkínálat a kifejezetten édes és sós ételekkel igyekszik befolyásolni az embereket, ami az evolúciós huzalozáson keresztül sérülékennyé teszi a mai kor emberét, hiszen ezek az ízpreferenciák vésődtek be őseinknél a túlélés érdekében (Logue, 2004; Rozin, 2004). Őseink idején az éhezés a túlélést fenyegető jelenség volt, ami versengési folya- matokat tett szükségessé, tehát a minél nagyobb mennyiségű étel birtoklása és elfogyasztása akkoriban a túlélés eszköze volt. Manapság azonban az elhízást eredményezi ez a stratégia (Gatward, 2007). Az ember azonban nem teljesen kiszolgáltatott ezeknek a bevésődött mechanizmusoknak, hanem tudatos stratégiákkal a modern korban is maradhatunk egészségesek. A tűzoltók körében fentebb bemutatott, szolgálatteljesítés közben alkalmazott evési stratégia az energiaraktárok biztosítására szintén a „túlélést szolgálja”. Mivel kiszámíthatatlan, milyen számú és gyakoriságú riasztás következik az előttük álló 24 órában, érdemes akkor táplálkozni, amikor az élelem hozzáférhető.

A szociokulturális tényezők jelentős befolyással vannak az elfogyasztott étel mennyiségére és a választott ételválasztásra egyaránt ahogyan az már a tűzoltó laktanyák étkezési szokásai kapcsán bemutatásra került. $\mathrm{Na}$ gyobb mennyiséget, gyorsabban és hosszabb ideig esznek az emberek (és az állatok egyaránt), ha társaságban vannak (De Castro, 1990; Forgács, 2004). A csábításnak való ellenállás állandó kihívás kultúránkban, hiszen a szeretetkifejezés egyik módja az evés és az etetés (Buckroyd és Rother, 2007). Nemet mondani igen nehéz, nem szívesen bántjuk meg a másikat.

Összességében a túltáplálkozás és a fizikai aktivitás hiánya játssza a legmeghatározóbb szerepet az elhízás kialakulásában. Az életvezetésben azonban a pszichológiai tényezők kiemelt jelentőségűek, ami elsősorban a stressz menedzselésében mutatkozik meg. A stresszhatások prediktorai a ritkább fizikai aktivitásnak, testedzésnek, az ülő életmódnak (Stults-Kolehmainen és Sinha, 2014), fokoz- 
zák az étvágyat, elsősorban az intenzív ízű, főként magas kalóriatartalmú ételek iránt (Torres és Nowson, 2007). Az evés ezáltal maladaptív többletfunkciót tölt be a stresszel szembeni védekezésben, mivel önjutalmazás és érzelemszabályozás eszközévé válik. Az érzelmi evés sürgetettségérzéssel jár, nem ismeri a mértékletességet, mivel a szervezet teltségjelzését figyelmen kívül hagyja, és gyakran bűntudattal végződik.

\section{Motiváció a változásra}

Ismerve az elhízás egészségügyi és pszichológiai szövődményeit, logikus következtetés lehetne, hogy kellő motivációt nyerhet az egyén az életmódváltozásra, ezáltal professzionális területről további segítségnyújtásra nincs szükség. A tűzoltó populáció esetében a szolgálatból való kiesés problémája és a munkahely megőrzésének célkitűzése tovább erősíthetné a motivációs bázist, azonban nem ilyen egyértelműek az összefüggések. A pszichológiai intervenciók szerepe ezen a ponton válik elsődlegessé, hiszen az életmódváltás folyamata sok kihívással és csalódással szembesíti az egyéneket. Elsődleges, hogy az érintettekkel szemben nem szabad a sztereotípiák, előítéletek térhódítását engedni. A megértés és a személyre szabott támogatás kialakítása elengedhetetlen ezen a ponton, hiszen figyelembe kell vennünk az elhízással küzdő populáció heterogenitását (Teixeira és tsai, 2005).

A pszichológiai okok mellett pszichológiai következményekkel is számolnunk kell az elhízott személyek esetében, hiszen a nyugati társadalmakban negatív megítélése van a súlyfeleslegnek. Amennyiben a probléma megol- dás nélkül marad, krónikus stresszfaktorral kell szembenézniük az érintetteknek.

A pszichológiai irányultságú egyéni vagy csoportos tréning bevezető szakaszaként érdemes néhány motivációt alapozó módszerrel kezdeni. Néhány kérdés megfogalmazása eredményes lehet:

- Hogyan fogalmaznám meg a konkrét problémát? (példa: "A munkahelyem és az egészségem megőrzése érdekében testsúlycsökkenésre van szükség.’”)

- Mennyire fontos nekem a megoldás? (példa: 1-5 fokozatú Likert-skálán: „egyáltalán nem fontos” - „,nagyon fontos”)

- Milyen ötleteim/lehetőségeim vannak a megoldásra? (példa: „Egészségesebb ételeket fogyasztok.”)

- Milyen tulajdonságaim, képességeim, személyiségvonásaim lesznek segítségemre? (példa: kitartás, alkalmazkodó készség, nyitottság)

- Milyen problémákat/feladatokat sikerült már megoldanom korábban? (példa: „Javítottam a fizikai felmérőn nyújtott teljesítményemen.”)

- Kik lesznek segítségemre a megoldásban? (példa: orvos, pszichológus, család)

- Milyen akadályozó tényezőkkel kell szembenéznem? (példa: „Ha unatkozom, evéssel töltöm ki az időm.”)

- Miért lesz előnyös számomra a probléma megoldása? (példa: „Megszűnik a gyakori hátfájásom is.")

Fontos szabály, hogy minden kérdésnél arra ösztönözzük a résztvevőt, hogy minél több válasza legyen. A probléma megfogalmazásánál és a fontosság megbecsülésénél a motivációelemzés és a konkrét, reális célkitüzés történik. Az ötletek, lehetôségek össze- 
gyújtése a személyre szabott megoldáskeresést, a széles körű megközelítést teszi lehetővé. Hosszú távon is hasznosnak bizonyul, hiszen a kudarcok megtapasztalásánál újabb lépések vagy egy másik út választása fenntartja a kitartást. A saját erôsségek tudatosítása a magabiztosság és az egyéni felelősség növelésére, a belsô kontrollos attitűd fenntartására alkalmas. A korábbi sikeres tapasztalatok felidézése (természetesen bármilyen területen, nemcsak az adott problémához kapcsolódóan) már kipróbált, eredményes módszerekkel szolgálhat, valamint szintén az önbizalmat erôsíti. A támogató személyek tudatosítása biztonságot nyújthat azáltal, hogy akadályokba ütközve is elérhető segítség, az egyén nincs egyedül.

Mivel gyakran minden igyekezet és optimális körülmény ellenére nem érkezik a kívánt eredmény, érdemes az akadályozó tényezők figyelembe vétele is, hiszen ezekre újabb megoldási stratégiák tervezhetőek. Végül az előnyök felsorakoztatása egészében a motivációerősítés módja.

További lehetőség a viselkedésváltozás transzteoretikus modelljének (Prochaska, Norcross és DiClemente, 2009) alkalmazása, mivel ennek segítségével megállapítható, melyik fázisban tart a viselkedésváltozás folyamatában a résztvevő személy. Ez alapján az elhízással érintettek heterogenitását megfelelően szűrhetjük már a bemeneti szakaszban, motivációs interjú alkalmazásával. Az 1. táblázat bemutatja a modell hat egymást követő stádiumát.

A fontolgatás előtti szakaszban tartó személyek nem terveznek testsúlycsökkenést az elkövetkezendő időszakban (megközelítőleg 6 hónapon belül).
A fontolgatás fázisában ugyan aktív lépések még nem történtek, de szándékukban áll fél éven belül valamilyen testsúlycsökkentő programban részt venni. A súlycsökkentéssel kapcsolatos előnyök-hátrányok egyensúlya még kiegyenlített, ezért ez a kategória sem alkalmas még arra, hogy a hagyományos intervenciók elinduljanak.

1. táblázat. A változás transzteoretikus modelljének szakaszai (Prochaska, Norcross és DiClemente, 2009)

A változás szakaszai

1. Fontolgatás előtti szakasz

2. Fontolgatás szakasza

3. Felkészülés szakasza

4. Cselekvés szakasza

5. Fenntartás szakasza

6. Befejezés szakasza

A felkészülés idején már néhány hétköznapi változás bekövetkezett (pl. lift helyett lépcső használata), elképzelhető, hogy szakemberrel történő konzultáció vagy egyéb információgyűjtés történt is a potenciális testsúlycsökkentési módszerekről. Az ebben a fázisban tartó személyek készen állnak arra, hogy cselekvésorientált programban vegyenek részt.

Azok, akik az első hat hónapon belül tartanak, és már aktív tevékenységekkel az egészségfejlesztésükért dolgoznak, a cselekvés stádiumában tartanak. Kisebb-nagyobb sikerek már tetten érhetőek ebben az időszakban, amit a környezet is észlel, és a pozitív visszajelzések által tovább erôsíthető az elkezdett folyamat. 
Azok, akiknek a kívánt súly megtartása minimum 6 hónapja sikerül, a fenntartás fázisába léptek át. Továbbra is aktív részvétel szükséges, és a pszichológiai háttértényezőkre még nagyobb hangsúly helyeződik (Czeglédi, 2012). Az étrenddel kapcsolatos választási helyzetekben a kognitív és viselkedéses éberség nélkülözhetetlen (Kristal és tsai, 1999), hiszen állandó kísértéseknek szükséges továbbra is ellenállni, és folyamatos erőfeszítést igényel a fizikai aktivitás szinten tartása is.

Végül a befejezést elérō egyének már stabilan ellenállnak, maximálisan támaszkodni tudnak az elsajátított megküzdési módokra, magabiztosak, és konzisztensen az új egészségmagatartás határozza meg mindennapjaikat.

\section{Pszichológiai intervenciók a testsúlycsökkentésben}

A legtöbb ember, aki az elhízás kezelésére keres megfelelő lehetőségeket, képes arra, hogy csökkentse testsúlyát. Azoknak a száma azonban elenyészőbb, akik képesek fenntartani azt a viselkedésváltozást, ami megelőzhetné a nemkívánt súly visszanyerését. Sajnos gyakori, hogy a többség több súllyal gyarapszik, mint amennyit korábban sikerült leadnia (Jones, Wilson és Wadden, 2007; Turk és tsai, 2009). Mindenekelőtt figyelembe kell venni néhány pszichológiai faktort, ami jelentôs befolyással bír a viselkedésváltozás hosszú távú eredményességére is. A változásra való készenlét (Czeglédi, 2012) a motivációs fázisok ismertetésénél már megbeszélésre került. A fogyás által elérni kívánt célok (Cooper, Fairburn és Hawker, 2003) tisztázása szintén alapvető fontosságú, hiszen a reális célok kitűzése nagyobb valószínűséggel ígér sikerélményt, ami fenntartja a kitartást.

A gondolkodási stílus (Cooper és Fairburn, 2001) a kognitív terápiás megközelítés alkalmazása révén kerül kiemelésre, mivel számos kognitív torzítás azonosítható, ami akadályozhatja a reális, kiegyensúlyozott gondolkodást.

Az érzelmi evésre való hajlam (Buckroyd és Rother, 2007) és a személy életében aktuális stresszorok feltérképezése szintén magasabb hatékonysági szintet ígér a kezelés során. Amennyiben az elhízásban érintett személy sikeresen elsajátít a stresszkezeléshez szükséges módszereket (például relaxációt), akár étrendi szigorítások nélkül is eredményes lehet a többletsúly kialakulásában és fennmaradásában közrejátszó evési mintázatok előfordulási gyakorisága (Czeglédi, 2016).

A reális célok kitűzése igen hangsúlyos a tűzoltók testsúlycsökkentő programjaiban is, főként azért, mert elsődlegesen egy orvos által elvárt testsúlynak kell megfelelniük. Az aktuális problémaövezet meghatározásához célszerű több mutató együttes figyelembe vétele: magasság, testsúly, testtömeg-index, testzsír-arány, haskörfogat (Gurevich és tsai, 2017). A súlycél meghatározásánál egy fél éven belül a 10\%-os súlyvesztés egészségesnek és sikeresnek tekinthető (Dalle Grave és tsai, 2005). Célszerű tekintetbe venni ezt a mutatót, hiszen a fogyással kapcsolatos túlzott elvárások miatt sokan idő előtt feladják a próbálkozást.

Megelőzésre szolgál az a tény is, hogy az aktív diétázás első hat hónapjának végére csökkenni kezd a leadott testtömeg aránya, ami komplex fiziológiai, pszichológiai és kör- 
nyezeti faktorok eredménye (Perri és Corsica, 2004). Mindezek a lépések elsődlegesen az egészségismeret fejlesztését célozzák.

A pszichológiai interakciók közül a pszichoedukáció után a kognitív (és) viselkedésterápiás és az önsegítő módszerek bevezetése javasolt. Az önsegítő módszerek kerete figyelemre méltó a tűzoltó populációban, hiszen Carter és Fairburn (1998) vezetésével egy 24 hetes program két, a terapeutával történő személyes találkozással és a köztes időben 15-20 perces telefonos ülésekkel valósult meg. Mivel a hivatásos állományon belül több földrajzi területről is érintettek lehetnek a tréningben résztvevők, és sokszor hosszabb utazással járhat a találkozások megoldása, az online és a telefonos kapcsolattartás preferálása - természetesen megfelelő edukációs felkészítést és állapotfelmérést követően- előnyösebb és kivitelezhetőbb lehet.

A viselkedésterápiában való egészségmenedzselési változások közül néhány javaslat a 2. táblázatban kerül bemutatásra.

A tréning egyéni és csoportos részében az aktív részvétel facilitálása létfontosságú. A résztvevők ezáltal nagyobb énhatékonyságot élnek meg, sikeresen gyakorolnak kontrollt a viselkedésváltozások fölött, ezáltal a tanult tehetetlenség jelensége is elkerülhetô, ami a komorbid depresszió veszélyét magában foglalhatja. Amennyiben észleli a résztvevő, hogy képes a változásra, kevésbé valószínú, hogy a kognitív torzítások közül az úgynevezett címkézés megjelenik nála. Jellegzetesen az „Én ilyen alkat vagyok.” automatizmus fordul elő, viszont a súlytöbblettel való szerepazonosulás akadálya lehet a változásnak, hiszen önbeteljesítő jóslatként hat, és jelentősen megszilárdítja az elhízással társuló egész-
2. táblázat. Néhány javasolt változás az egészségmagatartásban testsúlycsökkentés céljából (Perczel Forintos és Creglédi, 2011; Creglédi, 2012)

Javasolt változási módok az egészségmagatartásban a testsúlycsökkentés céljából

A napi kalóriabevitel korlátozása (életmódnak megfelelően).

A fóétkezések betartása, lehetőleg naponta azonos időpontban.

$\mathrm{Az}$ étkezéseket helyhez kötötten végezni (például mindig a konyhában).

Kisebb méretű tányér és evőeszközök használata.

Az étel alapos megrágása.

Evés közbeni figyelemelterelő tevékenység (például televíziózás, olvasás) kerülése.

Gyorséttermek kerülése, cukrozott üdítőitalok mellőzése.

Előretervezett, a napi rutinba illesztett testedzés.

Minél több lehetőség megragadása a mozgásra (például lift helyett lépcsőzés, autó helyett kerékpár használata, egy megállóval korábban leszállni az autóbuszról).

Evés helyett egyéb örömteli tevékenység beiktatása a distressz-érzés csökkentésére.

Élelmiszerboltban történő vásárlás csak étkezés utáni állapotban.

Evésnapló vezetése, melyben az evés ideje, helye, az étel és ital típusa, mennyisége, valamint a jelenlévő személy(ek) szerepel. Kiegészíthető az evési magatartáshoz társuló hangulat azonosításával.

Mindig részcélok kitűzése, és azok értékelése, külső visszajelzés kérésével kiegészítve. 
ségkárosító magatartásformákat. Minden esetben szükséges a negatív automatikus gondolatok és alapsémák azonosítása, melyek a hosszú távú terápiás eredményekhez szükségesek. A kognitív újrastrukturálás technikájával reálisabb, kiegyensúlyozottabb gondolatokkal végezheti a szükséges feladatokat az egyén.

A beavatkozások folyamatos figyelemmel kísérése szükséges a pszichológus részéről, ami az esetleges elakadásoknál biztonságot jelenthet a résztvevők számára. A támogató attitűd a teljes környezet részéről nélkülözhetetlen, hiszen az egészségkárosító magatartásban a kiváltó és fenntartó tényezők külső jelenléte komoly veszélybe sodorhatja a tréningek eredményességét. A csoportos intervenciók tehát preferáltabb módjai a viselkedésváltozásnak a tűzoltók körében is.

\section{Összegzés}

A bemutatásra került adatok alapján kiemelt fontosságú, hogy a tűzoltó populáció testtömeg-összetételét, táplálkozását, fizikai állóképességét figyelemmel kísérjük, és számukra a megfelelő multidiszciplináris segítséget biztosítsuk egészségi, pszichológiai és fizikai alkalmasságuk megőrzése érdekében. Az elhízás elterjedése veszélyezteti a hosszú távú zavartalan helytállást, és kezelése komoly erőfeszitést jelent. A prevenciós és intervenciós feladatok megtervezésénél szükséges azonosítani a lehetséges specifikus és általános rizikótényezőket, segíthetjük a megértést az elhízás etiológiájával kapcsolatos magyarázó elméletekkel, valamint a megfelelő motivációs szint elősegítésével. A pszichoedukációs szakaszt követően a kognitív (és) viselkedésterá- piás intervenciók, a relaxációs technikák és az önsegítő módszerek bevezetése hatékony megoldásnak ígérkezik. A káresemények alatt és azokat követően tanúsított bajtársias, egymást támogató attitűd a testsúlycsökkentés feladatában is előnyére válhat az állománynak, ezért a csoportos intervenciók előnyben részesítése javasolt. A testsúlykontroll lényegében egész életünkön át tartó feladat, ezért a prevenció elsődleges a megoldásban, illetve a megfelelő kezelési módszerek bevezetése is hatékonyabb, ha korai szakaszban történik.

\section{Irodalom}

Agne, A.A., Daubert, R., Munoz, M.L., Scarinci, I., \& Cherrington, A.L.(2012). The cultural context of obesity: Exploring perceptions of obesity and weight loss among Latina immigrants. J. Immigr. Minor. Health, 14(6), 1063-1070. doi: http://dx.doi.org/10.1007/s10903-0119557-3

Buckroyd, J. \& Rother, S. (2007). Therapeutic groups for obese women. $A$ Group Leader's Handbook. Chichester: John Wiley \& Sons Ltd.

Carter, J.C., \& Fairburn, C.G.(1998). Cognitive-behavioral self-help for binge eating disorder: a controlled effectiveness study. Journal of Consulting and Clinical Psychology, 66, 616-623. doi: http:// dx.doi.org/10.1037/0022-006X.66.4.616

Choi, B., Schnall, P., Dobson, M., Israel, L., Landsbergis, P., Galassetti, P., Pontello, A., Kojaku, S., \& Baker D. (2011). Exploring occupational and behavioral risk factors for obesity in firefighters: A theoretical framework nd study design. 
Saf Health Work, 2(4), 301-312. doi: http://dx.doi.org/10.5491/SHAW.2011. 2.4.301

Choi, B., Dobson, M., Schnall, P., \& GarciaRivas, J. (2016). 24-hour work shifts, sedentary work, and obesity in male firefighters. American Journal of Industrial Medicine, 59(6), 486-500. doi: http://dx.doi.org/10.1002/ajim.22572

Chung, N.K., \& Pin, C.H. (1996). Obesity and the occurence of heat disorders. Mil. Med., 161, 739-742.

Cooper, Z., \& Fairburn, C.G. (2001). A new cognitive-behavioral approach to the treatment of obesity. Behav. Res. Ther., 39(5), 499-511.

Cooper, Z., Fairburn, C.G., \& Hawker, D.M. (2003). Cognitive-behavioral treatment of obesity. A clinician's guide. New York, London: Guilford Press.

Czeglédi, E. (2012). A viselkedésváltozás transzteoretikus modelljének alkalmazási lehetőségei az elhízás kezelésében. Mentálbigiéné és Pszichoszomatika, 13(4), 411-434. doi: https://doi.org/10.1556/Mental.13. 2012.4.4

Czeglédi E. (2016): A stresszkezelés alkalmazási lehetőségei az elhízás kezelésében. Orvosi Hetilap, 157(7), 260-267. doi: http://dx.doi.org/10.1556/650.2016.303 $\underline{62}$

Dalle Grave, R., Calugi, S., Molinari, E., Petroni, M.L., Bondi, M., Compare, A., \& Marchesini, G. (2005). Weight loss expectations in obese patients and treatment attrition: An observational multicenter study. Obes. Res., 13, 19611969. doi: $\underline{10.1159 / 000441366}$
De Castro, J.M. (1990). Social facilitation of duration and size but not rate of the spontaneous meal intake of humans. Psychology and Behavior, 47, 1129-1135. doi: http://dx.doi.org/10.1016/00319384(90)90363-9

de Wit, L., Luppino, F., van Straten, A., Penninx, B., Zitman, F., \& Cuijpers, P. (2010). Depression and obesity: A metaanalysis of community-based studies. Psychiatry Research, 178(2), 230-235. doi: http://dx.doi.org/10.1016/j.psychres.200 $\underline{9.04 .015}$

Davidson, M., \& Knafl, K.A.(2006). Dimensional analysis of the concept of obesity. J. Adv. Nurs., 54(3), 342-350. doi: http://dx.doi.org/10.1111/j.13652648.2006.03812.x

Dobson, M., Choi, B., Schnall, P.L., Wigger, E., Garcia- Rivas, J., Israel, L., \& Baker, D.B. (2013). Exploring occupational and health behavioral causes of firefighter obesity: A qualitative study. American Journal of Industrial Medicine, 56(7), 776-790. doi: http://dx.doi.org/10.1002/ajim.22151

Donoghue, A.M., \& Bates, G.P. (2000). The risk of heat exhaustion at a deep underground metalliferous mine in relation to body-mass index and predicted $\mathrm{VO}_{2} \max$. Occup. Med. (Lond.), 50, 259-263. doi: http://dx.doi.org/10.1093/occmed/50.4. 259

Erdei, G., Kovács, V.A., Bakacs, M., \& Martos, É. (2017). Országos Táplálkozás és Tápláltsági Állapot Vizsgálat 2014. I. A magyar felnőtt lakosság tápláltsági állapota. Orv Hetil., 158, 533-540. doi: 10.1556/650.2017.30700 
Flegal, K.M., Kit, B.K., Orpana, H., \& Graubard, B.I. (2013). Association of allcause mortality with overweight and obesity using standard body mass index categories: A systematic review and metaanalysis. JAMA, 309(1), 71-82. doi: http://dx.doi.org/10.1001/jama.2012.113 $\underline{905}$

Forgács, A. (2004). Az evés lélektana. Budapest: Akadémiai Kiadó. doi: $10.1556 /$ $\underline{9789634541752}$

Forgács, A. (2008). Az íz- és ételpreferenciák szociokulturális háttere. In: Túry, F., \& Pászthy B. (szerk.): Evészavarok és testképzavarok. (pp.353-365) Budapest: Pro Die Kiadó.

Gariepy, G., Nitka, D., \& Schmitz, N. (2010). The association between obesity and anxiety disorders in the population: A systematic review and meta-analysis. International Journal of Obesity, 34(3), 407-419. doi: http://dx.doi.org/10.1038/ijo.2009. $\underline{252}$

Gatward, N. (2007). Anorexia nervosa: An evolutionary puzzle. European Eating Disorders Review, 15, 1-12. doi: http:// dx.doi.org/10.1002/erv.718

Geibe, J.R., Holder, J., Peeples, L., Kinney, A.M., Burress, J.W., \& Kales, S.N. (2008). Predictors of on-duty coronary events in male firefighters in the United States. Am. J. Cardiol., 101(5), 585-589. doi: http://dx.doi.org/10.1016/i.amjcard.200 7.10.017

Gu, J.K., Charles, L.E., Bang, K.M., Ma, C.C., Andrew, M.E., Violanti, J.M., \& Burchfiel, C.M. (2014). Prevalence of obesity by occupation among US workers: The National Health Interview Survey
2004-2011. J. Occup. Environ. Med., 56(5), 516-528. doi: http://dx.doi.org/10.1097/ JOM.0000000000000133

Gurevich, K.G., Poston, W.S.C., Anders, B., Ivkina, M.A., Archangelskaya, A., Jitnarin, N., \& Starodubov, V.I. (2017). Obesity prevalence and accuracy of BMI-defined obesity in Russian firefighters. Occupational Medicine, 67, 61-63. doi: http://dx.doi. org/10.1093/occmed/kqw136

Gyökeres, T., Király, Á., Lakatos, L., \& Madácsy L. (2006). Az elhizás szerepe a gasztroenterológiai kórképekben. Lege Artis Mediciane, 16(6), 527-533.

Hu, F.B. (2008). Obesity epidemiology. New York: Oxford University Press. doi: http://dx.doi.org/10.1093/acprof:oso/97 $\underline{80195312911.001 .0001}$

International Association of Fire Fighters. (2008). The Fire Service Joint Labor Management Wellness-Fitness Initiative. Washington, DC: International Association of Fire Fighters.

Jahnke, S.A., Poston, W.S.C., Haddock, C.K., \& Jitnarin, N. (2013) Obesity and incident injury among career firefighters in the Central United States. Obesity, 21(8), 15051508. doi: http://dx.doi.org/10.1002/ oby. 20436

Jones, L.R., Wilson, C.I., \& Wadden, T.A.(2007). Lifestyle modification in the treatment of obesity: an educational challengeand opportunity. Clinical Pharmacology \& Therapeutics, 81, 776-779. doi: $\quad$ http://dx.doi.org/10.1038/sj.clpt. $\underline{6100155}$

Kales, S.N., Soteriades, E.S., Christophi, C.A., \& Christiani, D.C. (2007). Emergency duties and deathes from heart 
disease among firefighters in the United States. N. Engl. J. Med., 356(12), 12071215. doi: 10.1056/NEJMoa060357

Kristal, A.R., Glanz, K., Curry, S.J., \& Patterson, R.E. (1999). How can stages of change be best used in dietary interventions? Journal of the American Dietetic Association, 99(6), 679-684. doi: $\underline{10.1016 / \mathrm{S} 0002-8223(99) 00165-0}$

Logue, A.W.(2004). The psychology of eating and drinking. New York: Brunner-Routledge. doi: https://doi.org/10.2752/155280106 $\underline{778055226}$

McGee, D.L.; Diverse Populations Collaboration (2005). Body mass index and mortality: A meta-analysis based on person-level data from twentysixobservazional studies. Ann Epidemiol, 15(2), 87-97. doi: 10.1016/j.annepidem. 2004.05.012

Moore, A.M. (2003). Cardiovascular disease: a continuing threat to homeland defense. J. Clin. Hypertens., 5, 350-351. doi: 10.1111/j.1524-6175.2003.02286.x

National Institute of Health (NIH) (1998). Clinical guidelines on the identification, evaluation and treatment of overweight and obesity in adults: The evidence report. Obes Res 6(S2), 51S-209S.

Net Jogtár. Letöltés ideje: 2020.04.12. Web: https:// net.jogtar.hu/jogszabaly?docid=a 0900057.irm

Pados, Gy., Audikovszky, M., \& Simonyi, G. (2017). Az obesitas diétás kezelése. In: Bedros, J.R. (szerk.). Klinikai obezitológia. (pp.117-137) Budapest: Semmelweis Kiadó.

Pandalai, S.P., Schulte, P.A., \& Miller, D.B. (2013). Conceptual heuristic models of the interrelationships between obesity and the occupational environment. Scand. J. Work Environ Health, 39(3), 221-232. doi: $10.5271 /$ sjweh.3363

Perczel Forintos, D., \& Czeglédi, E. (2011). Az elhízás kognitív (és) viselkedésterápiás megközelítési lehetőségei. In: Túry, F. \& Pászthy, B.( szerk.). Az evésqavarok pszichoterápiájának aktuális kérdései.(pp. 36-59) Budapest: Semmelweis Kiadó.

Perri, M.G., \& Corsica, J.A. (2004). Improving the maintenance of weight loss in behavioral treatment of obesity. In: Wadden, T.A., Stunkard, A.J., (szerk.). Handbook of obesity treatment. (pp. 357-379). New York: Guilford Press.

Pi-Sunyer, F.X. (2002). The obesity epidemic: Pathophysiology and consequences of obesity. Obesity Research, 10(S2), 97-104. doi: $10.1038 /$ oby.2002.202

Poplin, G.S., Harris, R.B., Pollack, K.M., Peate, W.F., \& Burgess, J.L. (2012). Beyond the fireground: injuries in the US fire service. Injury Prev., 18, 228-233. doi: 10.1136/injuryprev-2011-040149

Poplin, G.S., Roe, D.J., Peate, W., Harris, R.B., \& Burgess, J.L. (2014). The association of aerobic fitness with injuries in the fire service. Am. J. Epidemiol. , 179(2), 149-155. doi: https://doi.org/ 10.1093/aje/kwt213

Poston, W.S., Haddock, C.K., Jahnke, S.A., Jitnarin, N., Tuley, B.C., \& Kales, S.N. (2011). The prevalence of overweight, obesity, and substandard fitness in a population-based firefighter cohort. J.Occup. Environ Med., 53, 266-273. doi: 10.1097/JOM.0b013e31820af362 
Prochaska, J.O., Norcross, J.C., \& DiClemente, C.C. (2009). Valódi újrakezdés. Hatlépcsös program ártalmas szokásaink leküzdésére és életünk jobbá tételére. Budapest: Ursus Libris.

Rozin, P. (2004). Sociocultural influences on human food selection. In: Capaldi, E.D. (szerk.): Why we eat what we eat? The psychology of eating. (pp.233-263) Washington DC: American Psychological Association. doi: https://doi.org/ $\underline{10.1037 / 10291-009}$

Sidó, Z. (2003). Korunk epidémiája: az elhízás. Lege Artis Mediciane, 13(7), 541-545.

Soteriades, E.S., Smith, D.L., Tsismenakis, A.J., Baur, D.M., \& Kales, S.M. (2011). Cardiovascular disease in US firefighters: a systematic review. Cardiol. Rev., 19, 202215. doi: 10.1097/CRD.0b013e3182 $\underline{15 \mathrm{c} 105}$

Stults-Kolehmainen, MA., \& Sinha, R. (2014). The effects of stress on physical activity and exercise. Sports Med., 44(1), 81-121. doi: $\underline{10.1007 / s 40279-013-0090-5}$ Teixeira, P.J., Going, S.B., Sardinha, L.B., \& Lohman, T.G. (2005). A review of psychosocial pre-treatment predictors of weight control. Obes. Rev., 6(1), 43-65. doi: 10.1111/i.1467-789X.2005.00166.x

Torres, S.J., \& Nowson, C.A. (2007). Relationship between stress, eating, behavior, and obesity. Nutrition, 23(1112), 887-894. doi: 10.1016/j.nut.2007. $\underline{08.008}$

Turk, M.W., Yang, K., Hravnak, M., Sereika, S.M., Ewing, L.J., \& Burke, L.E. (2009). Randomized clinical trials of weight loss maintenance: a review. Journal of Cardiovascular Nursing, 24, 58-80. doi: 10.1097/01.JCN.0000317471.58048.32

World Health Organization (WHO) (2000).

Obesity: Preventing and managing the global epidemic. Geneva: WHO 